Herman van Dekken • Carla Rosenberg

Pieter J. Krijtenburg • Janneke C. Alers

\title{
Interphase cytogenetics and comparative genomic hybridization of human epithelial cancers and precursor lesions
}

Accepted: 27 June 1997

\begin{abstract}
The accuracy of cytogenetic analyses of human solid cancers has improved enormously over the past decade by the introduction and refinement of DNA in situ hybridization (ISH) techniques. This methodology can be applied to cells in the interphase state, thereby making it an excellent tool for the delineation of chromosomal aberrations in solid tumors. The use of non-isotopic ISH to intact and disaggregated cancer specimens will be discussed, as well as comparative genomic hybridization $(\mathrm{CGH})$ with tumor-derived DNAs. In this review we will focus on hybridocytochemical interphase approaches for the detection of chromosomal changes in frequently occurring human epithelial malignancies, e.g., breast, lung, and prostate carcinomas. We will further discuss the use of ISH procedures for the genetic analysis of precursor conditions leading to invasive carcinomas. Knowledge concerning these precancerous conditions is increasing, and its importance in cancer prevention has been recognized. Interphase cytogenetics by ISH, as well as CGH, with DNAs derived from microdissected, precancerous, dysplastic tissue areas will increase our understanding of these lesions, both at the investigative and diagnostic levels.
\end{abstract}

\section{Introduction}

In 1914, Theodor Boveri concluded in his classical work entitled "Zur Frage der Entstehung maligner Tumoren" that cancer is a genetic disease, caused by clonal chromosomal changes (Boveri 1914). Most of Boveri's statements eventually turned out to be true. However, it was

H. van Dekken ( $)$ P.J. Krijtenburg · J.C. Alers

Department of Pathology, Erasmus University Rotterdam,

PO Box 1738, NL-3000 DR Rotterdam, The Netherlands;

Tel. +31.10.408.7499; fax +31.10.436.6660

C. Rosenberg

Dr. Daniel den Hoed Cancer Center, Rotterdam, The Netherlands

C. Rosenberg

Department of Cytochemistry and Cytometry,

State University Leiden, Leiden, The Netherlands not until 1960 that the first consistent chromosomal abnormality was found in human tumor cells [i.e., the Philadelphia $(\mathrm{Ph})$ chromosome in chronic myelogenous leukemia; Nowell and Hungerford 1960]. With the subsequent introduction and continuous improvement of chromosome banding techniques, allowing reliable recognition of each chromosome and of sub-chromosomal structures, a large-scale search for specific karyotypic abnormalities could be initiated. Initially, most information was obtained from leukemia and lymphoma (Sandberg 1990). In two decades a vast amount of detailed information on the occurrence of chromosomal abnormalities in human cancer has been accumulated (see Sandberg 1990; Mitelman 1994 for reviews) and acquired clonal chromosomal aberrations have indeed been demonstrated to be a characteristic feature of tumor cells (Nowell 1976; Heim and Mitelman 1987; Sandberg 1990). The general view is that tumor initiation and progression is a multistep process, caused by an accumulation of genetic aberrations resulting in the activation of oncogenes and/or inactivation of tumor suppressor genes (Knudson 1971; Vogelstein et al. 1988; reviewed by Bishop 1991). In the last decade, precancerous lesions, such as large bowel adenomas or cervical dysplasias, have attracted much attention for their role in malignant transformation to invasive cancer (Rosai 1996). These precursor lesions have currently established their importance in cancer prevention and surveillance.

\section{In situ hybridization and comparative genomic hybridization of epithelial neoplasms}

Although solid tumors are much more frequent than hematological neoplasms, much less is known about the cytogenetic aberrations that characterize them. Mostly technical problems have for a long time hampered the acquisition of cytogenetic data on solid tumors (Sandberg 1990). Solid tumor biopsies yield low numbers of viable cells, have a low mitotic index, and frequently contain non-neoplastic cells. Furthermore, the quality of 
Table 1 Genetic alterations in frequently occurring human epithelial cancers (Alers and van Dekken 1996). (LOH Loss of heterozygosity, $I S H$ in situ hybridization, $C G H$ comparative genomic hy- bridization, $S C L C$ small cell lung cancer, $N S C L C$ non-small cell lung cancer, $i$ isochromosome)

\begin{tabular}{|c|c|c|c|c|}
\hline Organ & Karyotyping & $\mathrm{LOH}$ & ISH & $\mathrm{CGH}$ \\
\hline Lung (SCLC) & $\begin{array}{l}-3 p,-5,-5 q,-13 \\
-13 q,-17 p\end{array}$ & $3 p, 5 q, 13 q, 17 p$ & N-myc amplification & $\begin{array}{l}\text { Loss of } 3 p, 5 q, 13 q, 17 p \\
\text { gain of } 3 q, 5 p, 8 q, X q\end{array}$ \\
\hline Lung (NSCLC) & $\begin{array}{l}-3 p,-6 p,+7,+7 p \\
-9 p,-11 p,-17 p,-Y\end{array}$ & $\begin{array}{l}3 \mathrm{p}, 8 \mathrm{p}, 9 \mathrm{p}, 11 \mathrm{pq}, \\
13 \mathrm{q}, 17 \mathrm{p}\end{array}$ & $\begin{array}{l}+7,-17 \\
\text { loss of } \mathrm{p} 15 / \mathrm{p} 16\end{array}$ & $\begin{array}{l}\text { Loss and gain of several } \\
\text { chromosomal sequences }\end{array}$ \\
\hline Head and neck & $\begin{array}{l}-3 p, i(5 p), i(8 q),-8 p \\
-10 p, 11 q 13,-18 q,-Y\end{array}$ & $3 p, 8 p, 9 p q, 11 q$ & $\begin{array}{l}\text { int-2/hst- } 1 \text { amplifi- } \\
\text { cation at } 11 \mathrm{q} 13\end{array}$ & $\begin{array}{l}\text { Loss of 3p, 5q, 8p, 9p; } \\
\text { gain of 3q, 5p, 8q, 11q }\end{array}$ \\
\hline Esophagus & $-1 \mathrm{p},-4,11 \mathrm{p} 13,+20,-\mathrm{Y}$ & $5 q, 9 p, 13 q, 17 p$ & $+8,-17,-\mathrm{Y}$ & $\begin{array}{l}\text { Loss of } 8 p, 9 p, 16,17 \\
\text { gain of } 8 q, 20\end{array}$ \\
\hline Colorectum & $\begin{array}{l}-1 \mathrm{p},+7,-8 \mathrm{p}, \mathrm{i}(8 \mathrm{q}), \\
-17,-17 \mathrm{p},-\mathrm{Y}\end{array}$ & $5 q, 8 p, 17 p, 18 q$ & $+7,+8,-18$ & $\begin{array}{l}\text { Loss of } 9 p, 17,18 q \\
\text { gain of } 7,8 q, 13,20 q\end{array}$ \\
\hline Prostate & $+7,-7 \mathrm{q},-8 \mathrm{p},-10 \mathrm{q},-\mathrm{Y}$ & $\begin{array}{l}6 \mathrm{q}, 7 \mathrm{q}, 8 \mathrm{p}, 10 \mathrm{pq}, \\
13 \mathrm{q}, 16 \mathrm{q}, 18 \mathrm{q}\end{array}$ & $\begin{array}{l}+7,-8,+8,-10 \\
-18,-Y\end{array}$ & $\begin{array}{l}\text { Loss of } 6 \mathrm{q}, 8 \mathrm{p}, 13 \mathrm{q}, 16 \mathrm{q} \text {; } \\
\text { gai of } 7 \mathrm{p}, 7 \mathrm{q}, 8 \mathrm{q}, \text { Xq }\end{array}$ \\
\hline Bladder & $+7,-9,-11 \mathrm{p}$ & $\begin{array}{l}3 p, 9 p q, 11 p, 13 q, \\
17 p\end{array}$ & $\begin{array}{l}+1,+7,-9,+11,-17 \mathrm{p} \\
\text { amplification erbB-2 }\end{array}$ & $\begin{array}{l}\text { Loss of gain of several } \\
\text { chromosomal sequences }\end{array}$ \\
\hline Kidney & $\begin{array}{l}-3 p,-5 q,-6,+7,-14 \\
-14 q,-Y\end{array}$ & $\begin{array}{l}3 \mathrm{p}, 5 \mathrm{q}, 6 \mathrm{p}, 8 \mathrm{p}, 9 \mathrm{p} \\
14 \mathrm{q}, 17 \mathrm{pq}, 21 \mathrm{q}\end{array}$ & $-1,+7,+17,-17,-\mathrm{Y}$ & $\begin{array}{l}\text { Loss of } 1,2,3 p, 9 p, Y \\
\text { gain of } 1 \mathrm{q}, 5 \mathrm{q}, 7,16 \mathrm{p}\end{array}$ \\
\hline Breast & $\begin{array}{l}\mathrm{i}(1 \mathrm{q}),-1 \mathrm{q},-3 \mathrm{p},-6 \mathrm{q} \\
+7,+18,+20\end{array}$ & $\begin{array}{c}1 \mathrm{pq}, 3 \mathrm{p}, 6 \mathrm{q}, 7 \mathrm{q}, 8 \mathrm{p}, 9 \mathrm{p} \\
11 \mathrm{p}, 13 \mathrm{q}, 16 \mathrm{q}, 17 \mathrm{pq}, 18 \mathrm{q}\end{array}$ & $\begin{array}{l}+1,+7,-17 \mathrm{p}, \\
\text { amplification erbB-2 }\end{array}$ & $\begin{array}{l}\text { Loss of } 17 \mathrm{p}, 22 \mathrm{q} ; \\
\text { gain of } 1 \mathrm{q}, 8 \mathrm{q}, 17 \mathrm{q}, 20 \mathrm{q}\end{array}$ \\
\hline Ovary & $\begin{array}{l}-8,+12,-13,-14, \\
-17,-22,-X\end{array}$ & $3 p, 11 p, 13 q, 17 p q$ & $\begin{array}{l}+1,+7,+8,+11 \\
+11 \mathrm{q},+12 \mathrm{p},-17,-20\end{array}$ & $\begin{array}{l}\text { Loss of } 16 \mathrm{q}, 17 \mathrm{pg} ; \\
\text { gain of } 3 \mathrm{q}, 8 \mathrm{q}, 12 \mathrm{p}, 20 \mathrm{q}\end{array}$ \\
\hline
\end{tabular}

Table 2 Genetic alterations, detected by various methods, in defined precursor lesions of human epithelial cancers. [Metaplasia Transformation from respiratory into stratified squamous epithelium, DCIS ductal carcinoma in situ, IN intraepithelial neoplasia of $P$ prostate, $C$ uterine cervix, $O$ oral mucosa, $E$ esophagus, metaplasia (Barrett) transformation from stratified squamous into columnar epithelium]

\begin{tabular}{|c|c|c|c|}
\hline Organ & Carcinoma & Precursor & Aberrations \\
\hline Lung (bronchus) & Squamous cell ca. & Metaplasia & $-3 p,-5 q,+7,-9 p,-17 p$ \\
\hline Colon & Adenocarcinoma & Adenomatous polyp & $\begin{array}{l}-1 \mathrm{p},-5 \mathrm{q},+7,+13,-14,-15 \\
-17 \mathrm{p},-18,-18 \mathrm{q},+20,-21\end{array}$ \\
\hline Breast & Adenocarcinoma & DCIS & $\begin{array}{l}-1 \mathrm{p},+1 \mathrm{q},-6 \mathrm{q},-7 \mathrm{p},-8 \mathrm{p},-9 \mathrm{p},-11 \mathrm{p}, \\
-13 \mathrm{q},-16 \mathrm{q},-17 \mathrm{p},-17 \mathrm{q},+17 \mathrm{q},+20 \mathrm{q}\end{array}$ \\
\hline Prostate & Adenocarcinoma & PIN & $-8 \mathrm{p},-\mathrm{Y}$ \\
\hline Ovary & Adenocarcinoma & Borderline tumor & $+6,+7$ \\
\hline Uterine cervix & Squamous cell ca. & CIN & $-5 p$ \\
\hline Head and neck & Squamous cell ca. & Metaplasia/OIN & $-9 p$ \\
\hline Esophagus & Squamous cell ca. & EIN & $-9 q$ \\
\hline Esophagus & Adenocarcinoma & Metaplasia (Barrett) & $-5 \mathrm{q},-9 \mathrm{p},-17 \mathrm{p},-\mathrm{Y}$ \\
\hline
\end{tabular}

metaphases is relatively poor. Therefore, interphase approaches, both at molecular and cytological levels, are better equipped to disclose genetic changes occurring in human epithelial cancers (Table 1) and their precursor lesions (Table 2) (see also Alers and van Dekken 1996, and references therein). In this section we will review the literature concerning interphase DNA in situ hybridization (ISH), also termed interphase cytogenetics, as well as comparative genomic hybridization (CGH) of frequently occurring human epithelial neoplasms. In Figs. 1-3, examples (esophageal and prostatic cancer) are shown of ISH (Fig. 1) and CGH (Fig. 2) of invasive cancers and their precancerous conditions (Fig. 3).

\section{Lung cancer}

In the literature, a subdivision is often made between small cell lung cancers (SCLCs) and non-small cell lung cancers (NSCLCs), the latter comprising squamous cell carcinoma and adenocarcinoma. Interphase cytogenetics on paraffin sections of lung tumors by non-isotopic ISH
Fig. 1a-f Interphase in situ hybridization (ISH) of human epithelial cancers. a-c Esophageal cancer (Barrett's adenocarcinoma). a Hematoxylin-eosin stained section, showing tumor cells $(T)$, infiltrating the smooth muscle layer $(M)$ of the esophageal wall. b ISH with the chromosome 7-specific centromeric DNA probe to a routinely processed, formalin-fixed, paraffin-embedded tissue section of the same region. The ISH-related spots were visualized with immunoperoxidase/diaminobenzidine (black); hematoxylin was used as a counterstain (gray). Many cancer cell nuclei show aneusomic ISH spot numbers (a few are arrowed). c Same area of a consecutive tissue section, showing ISH with a chromosome 17 DNA probe. Many cancer cell nuclei with 0 or 1 spot are seen, illustrating loss of this chromosome. d-f Prostate cancer (bone metastasis). d ISH with the chromosome 1-specific centromeric DNA probe to a routinely processed, formalin-fixed, paraffin-embedded tissue section of a bone metastasis of prostatic adenocarcinoma. $\mathbf{e}$ Same tumor area on a consecutive section: ISH with a chromosome 8-specific centromeric DNA probe. Many tumor cell nuclei display aneusomy, indicating gain of this chromosome (compare with d). f Same area. Y-ISH, revealing loss of chromosome Y in the cancer cells, but not in stromal cells (arrows). A 40x objective was used, except for a $(20 \times)$ 


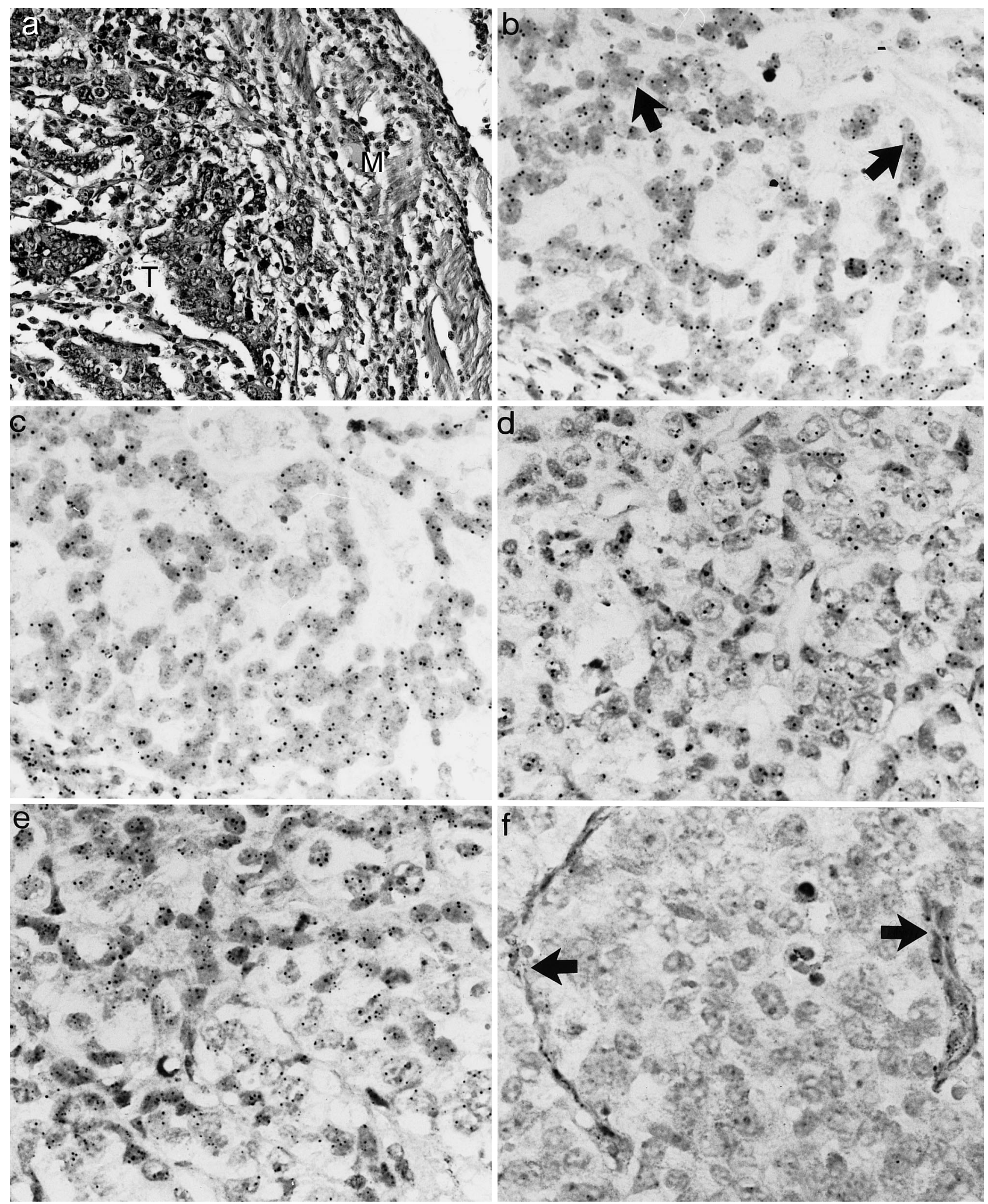

was also performed by Kim et al. (1993). ISH data were found to correlate with the DNA index, derived from image analysis of Feulgen-stained nuclei. However, in some cases, chromosome 7 or 17 was either over- or underrepresented compared with the DNA index. Fluores- cence ISH (FISH) analysis of a SCLC cell line elucidated the origin of homogeneously staining regions (HSRs; Dietzsch et al. 1994). These authors found the amplified region to contain the N-myc gene. Recently, the copy number of p15 and p16/MTS1, both located at 
Fig. 2a, b Comparative genomic hybridization (CGH) of human epithelial cancers. A Esophageal cancer (Barrett's adenocarcinoma): CGH of an archival, formalin-fixed, paraffin-embedded Barrett's adenocarcinoma (region shown in Fig. 1a). The chromosomal ideograms are shown together with the ratio profiles and the digitized fluorescent images of four selected chromosomes (measurements from five metaphases, lower/upper thresholds at ratios $0.85 / 1.15)$. Note both loss of the distal region (red) and gain of the proximal region (green) on the short arm of chromosome 8. Also loss on 9p and gain on 19q can be distinguished. Chromosome 17 displays losses on both arms, most likely caused by loss of a

whole chromosome (see interphase cytogenetics: Figs. 1b,

c). b Prostate cancer (bone metastasis): CGH of an archival, formation-fixed, paraffin-embedded bone metastasis of prostate adenocarcinoma (same as Fig. 1). Again, the chromosomal ideograms are shown together with the ratio profiles and the digitized fluorescent images of four selected chromosomes (measurements from thresholds at ratios 0.80/1.20). Gain is seen of 8q and on 10q, whereas losses can be detected on 8p, on 13q and of chromosome Y (compare ISH data in Fig. 1f). The gain of $8 \mathrm{q}$ involves the entire chromosome arm, while in Figs. 1d and e a gain of the chromosome 8 cenphase cytogenetics. This strongly suggest the presence of an isochromosome of the long arm of chromosome 8 seven metaphases, lower/upper tromere was disclosed by inter-

a CGH OF A BARRETT ADEHOCARCIHOHA
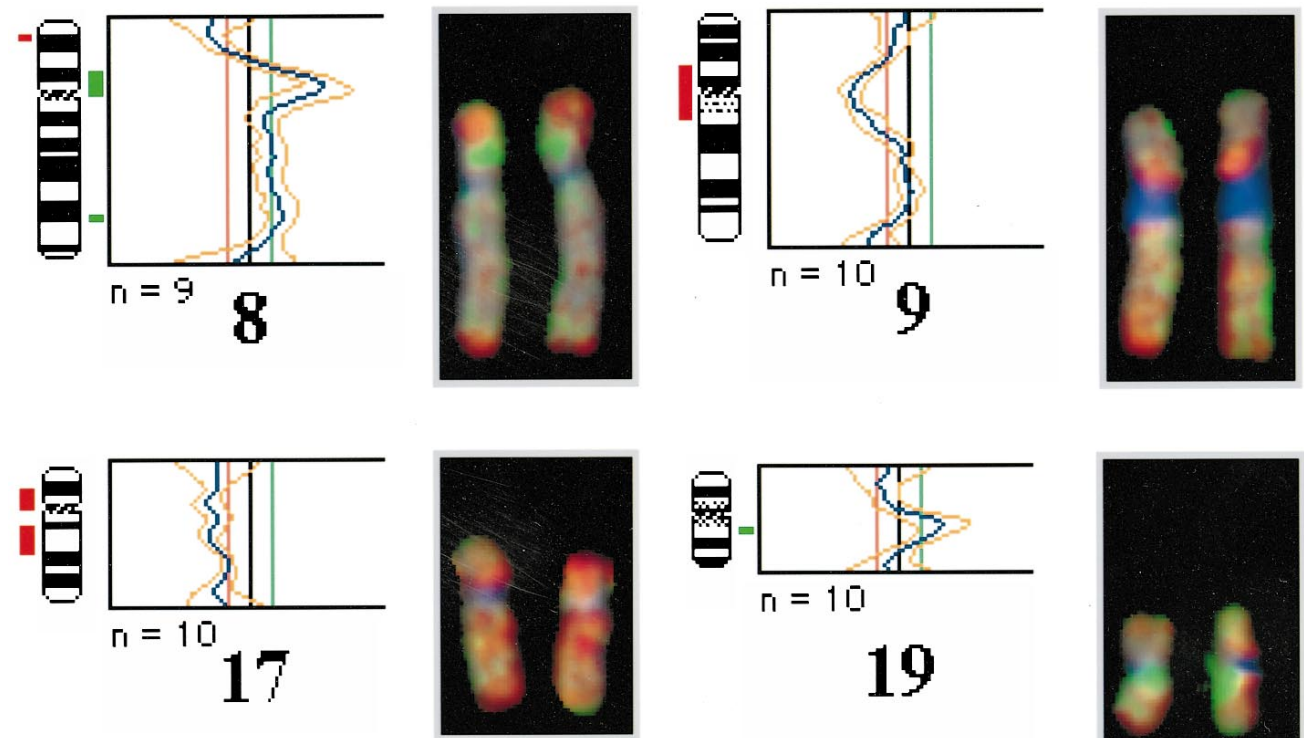

$\Gamma$
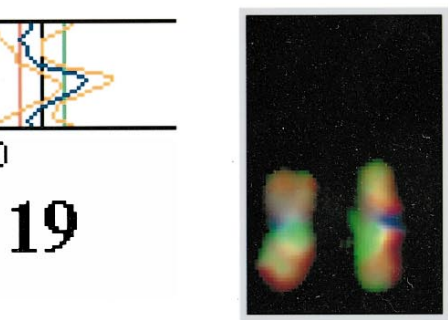

b

CGH OF A PROSTATE CANCER BOHE METASTASIS
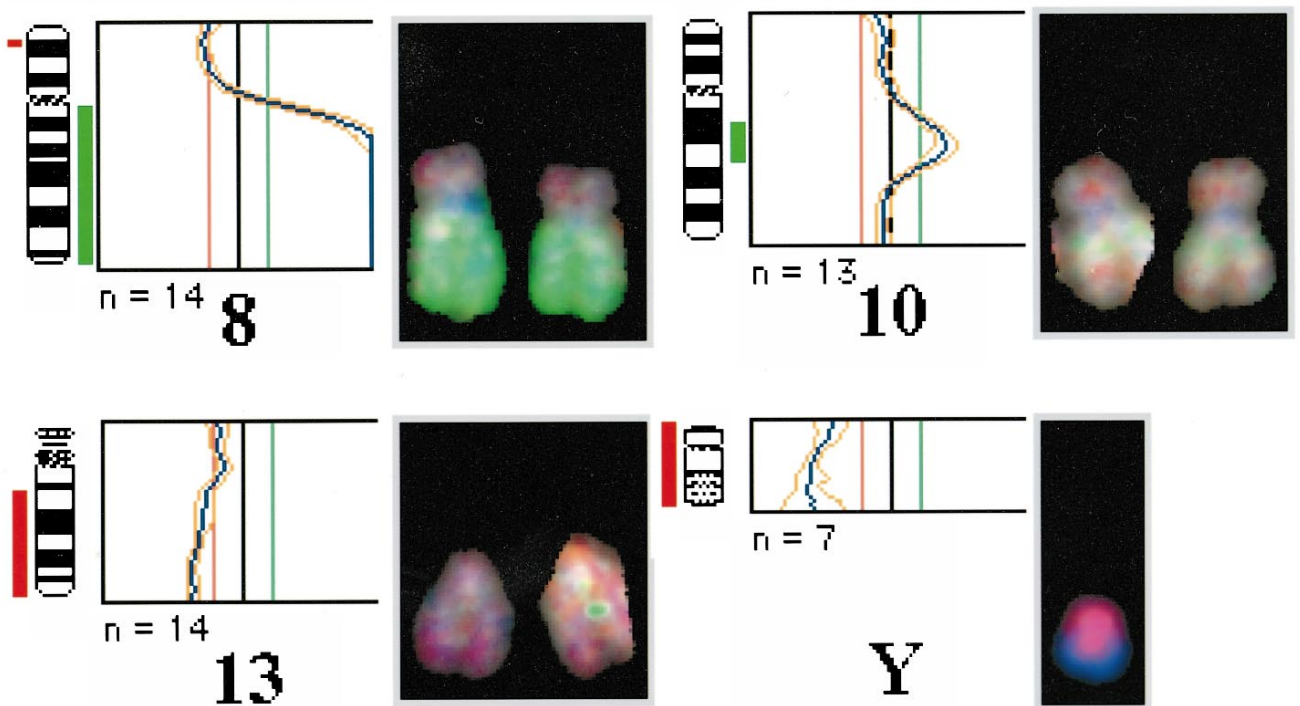

myc), 5p, 8q24 (c-myc), and Xq26. Decreases were found at 3p, 10q26, 13q14 (Rb) 16p11, 17p13 (p53), and $22 q 12-q 13$. The results, described above, were confirmed in recent investigations on larger panels of tumors (Levin et al. 1995; Petersen et al. 1997). concluded that p15 and p16 are deleted and/or mutated in most primary NSCLCs.

A CGH study of 13 primary SCLCs was performed by Ried et al. (1994). Losses of chromosome arms 3p, $5 q, 10 q, 13 q$, and $17 p$ were detected, as well as DNA gains of 3q, 5p, 8q, and 17q. The most frequently amplified site was 19q13.1. Further, a CGH study of SCLC cell lines by Levin et al. (1994) revealed increases in DNA sequences at regions 1p22 (L-myc), 2p24-p25 (N-

\section{Head and neck cancer}

Head and neck tumors consist mostly of squamous cell carcinomas (HNSCCs). Numerical aberrations of chromosome 17 were investigated in cell suspensions, derived from four oral tumors, by FISH with centromeric probes 
(Tsuji et al. 1994). The copy number of chromosome 17 significantly increased in oral malignant tumors compared to benign tumors. Worsham et al. (1995) demonstrated rearrangements of $\mathrm{Y}$ and aneuploidy in two synchronously arising primary squamous cell carcinomas (SCCs) and their recurrences. Moreover, these authors concluded that the FISH patterns and the presence of a clonal Y marker in all four tumor samples indicate a monoclonal origin of the synchronous primaries and their recurrences. Recently, Lese et al. (1995) visualized INT2 and HST1 amplification in oral SCCs, containing HSRs, by dual-color FISH with cosmid probes specific for the chromosome 11q13 region. Non-isotopic ISH on paraffin-embedded tissue sections of $25 \mathrm{HNSCC}$ using centromere probes specific for chromosomes 7 and 17, revealed polysomy in both premalignant and tumor tissue (Voravud et al. 1993). Moreover, the frequency of cells with polysomy increased as the tissues passed from histologically normal epithelium to hyperplasia to dysplasia to cancer.

A CGH analysis of 13 primary HNSCCs by Speicher et al. (1995) showed a frequent copy number increase on chromosome regions $3 q$ and $5 p$ and less frequently on 1q. Loss occurred most frequently at 3p, 5q, 19p, and $19 q$. Eight sites exhibiting sequence amplification were mapped to 3q26-qter, 11q13, 12p, 2q33-q36, 7q21-q22, 7q33-qter, 9p, and 13q23-qter. The authors suggest that the regions $3 q 26-q$ ter and $5 p$ may harbor oncogenes important in HNSCC development. A CGH study by Brzoska et al. (1995) of ten HNSCCs also identified gain of the chromosome 3q26-q27 region and loss of chromosome $3 p$ at high frequency (over $50 \%$ of cases). These findings were largely confirmed in a recent study of 30 HNSCCs (Bockmuhl et al. 1996). However, in addition to these changes, frequent losses were seen of $1 p, 8 p, 9 p$, and $13 q$, as well as frequent gains of $8 q$ and 19 .

\section{Esophageal cancer}

In the esophagus, the incidence of adenocarcinoma is increasing rapidly, now equalling that of SCC. Most esophageal adenocarcinomas arise in so-called Barrett's epithelium, a precancerous lesion near or at the gastro-esophageal junction. ISH applied to archival tissue sections of 14 adenocarcinomas of the esophagus using three chromosome Y-specific DNA probes showed absence of the $\mathrm{Y}$ chromosome in $93 \%$ of the adenocarcinomas (Hunter et al. 1993). FISH on nuclear suspensions of ten gastric adenocarcinomas also revealed loss of the Y chromosome in a high percentage of male patients (van Dekken et al. 1990a). In a study by our group of four archival adenocarcinomas, loss of the $\mathrm{Y}$ chromosome, overrepresentation of chromosome 8, and loss of chromosome 17 were observed. In two tumors, negative for p53 protein immunohistochemistry, loss of 17 was found (Krishnadath et al. 1994). In another study, aneuploidy, as determined by ISH for chromosome 1, and loss of Y correlated with progression from metaplasia to dysplasia to carcinoma (Krishnadath et al. 1995). Loss of
$\mathrm{Y}$ and aneuploidy for chromosome 1 reached high prevalences in high-grade dysplasia and adenocarcinoma. Hunter et al. (1993) observed absence of the Y chromosome in $62 \%$ of SCCs of the esophagus. A preliminary CGH study by our group disclosed frequent gain of $8 \mathrm{q}$ and chromosome 20, as well as loss of 8p, 9p, 16, and 17 sequences in adenocarcinomas (C. Rosenberg and H. van Dekken, unpublished results).

\section{Colorectal cancer}

Colorectal adenocarcinomas arise, in general, in adenomatous polyps. Cajulis and Frias-Hidvegi (1993) showed gain of chromosome 8 in one out of three fine-needle aspirates from colon adenocarcinomas. FISH applied to single-cell suspensions of 35 colonic adenomas revealed trisomy of chromosome 7 in over one-third of cases (Herbergs et al. 1994). In nearly half of the cases, this aberration was combined with abnormalities of the other chromosomes investigated. ISH applied to 23 archival advanced stage colon cancer specimens, revealed three to eight copies of chromosomes 8, 12, and 17 (Steiner et al. 1993). The mean frequency of multiple copies for chromosome 12 was significantly greater than that for chromosome 17. Chen and Nierman (1994) used chromosome painting by FISH with library probes to examine abnormalities identified by G-banding in two colon cancer cell lines, DLD-1 and HCT-15. Trisomy of chromosome 20 and trisomy of the 2p13-p23 segment were seen in the DLD-1 cell line, whereas in HCT-15, a $\mathrm{t}(16 ; 16)$ and gain of Y were seen. Recently, Sasaki et al. (1995) demonstrated monosomy of chromosome 18 in one-third of cases using FISH on suspensions derived from early carcinomas without foci of adenoma. Suspensions derived from more advanced cancers showed monosomy 18 in $44 \%$ of cases.

In addition to these ISH data, $\mathrm{CGH}$ revealed gain of chromosomes 7, 13, and 20q, whereas loss was seen of 9p, 17, and 18 (Schlegel et al. 1995). Ried et al. (1996) identified gain of 7 in low-grade adenomas, whereas in high-grade adenomas gain of chromosome 20 also occurred. Further, the transition from adenoma to carcinoma was characterized by multiple additional alterations, such as loss of $18 \mathrm{q}$ or gain of $8 \mathrm{q}$.

\section{Prostate cancer}

The vast majority of prostatic cancers are adenocarcinomas. Many studies have been reported concerning (F)ISH to nuclear suspensions and paraffin sections of prostatic cancer. Numerical aberrations of chromosomes 7, 8, 10, 16, 17, 18, and $\mathrm{Y}$ were revealed (van Dekken et al. 1990b; van Dekken and Alers 1993; Baretton et al. 1994; Brown et al. 1994; Henke et al. 1994; Jones et al. 1994; Visakorpi et al. 1994; Zitzelsberger et al. 1994; Alers et al. 1995a). Furthermore, FISH studies of nuclear suspensions or touch imprints of prostatic tumors revealed that 


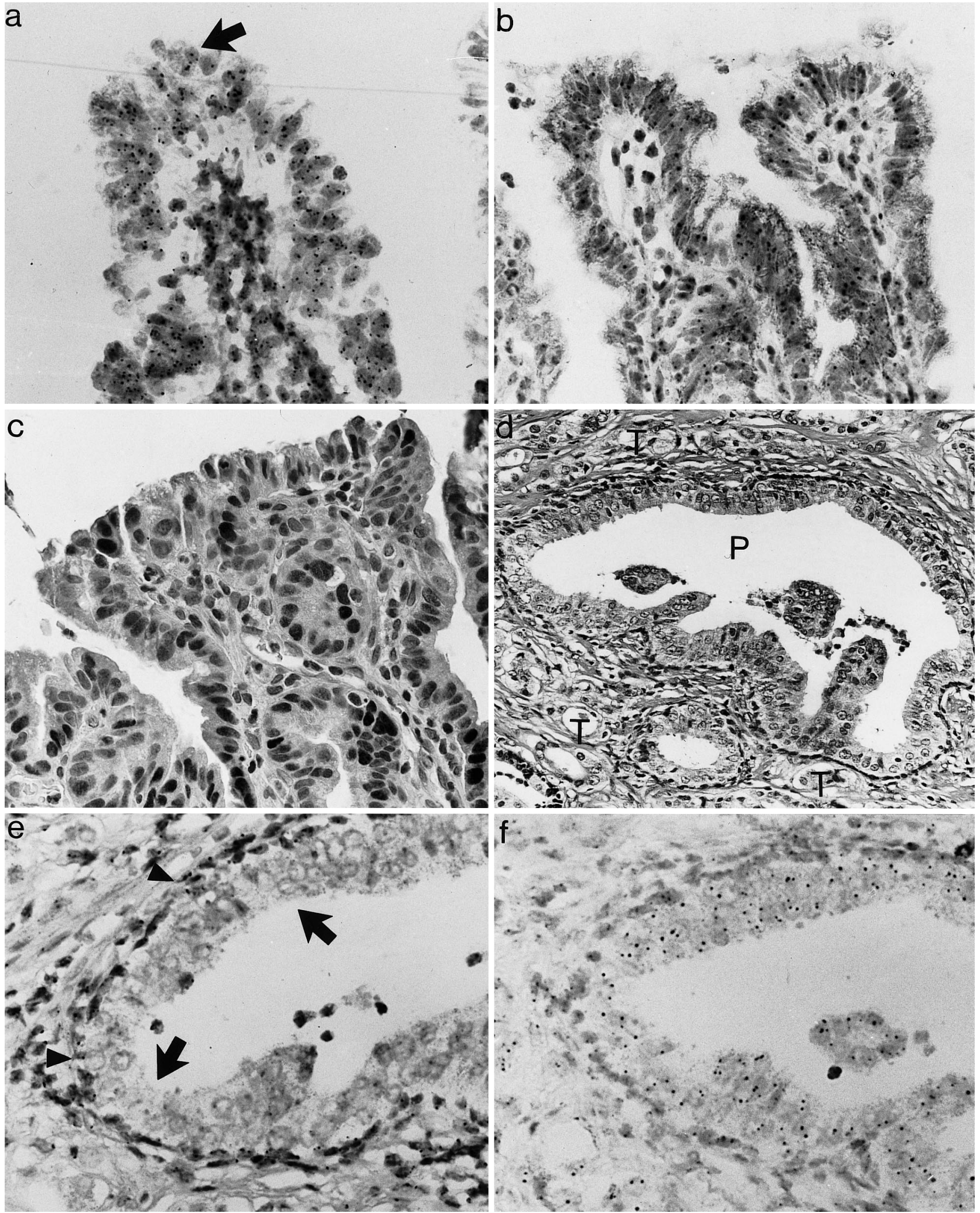

Fig. 3 
alterations of chromosomes 7 and 8 are potential markers of poor prognosis in prostate cancer (Alcaraz et al. 1994; Bandyk et al. 1994; Takahashi et al. 1994). A combined ISH and CGH analysis showed that gain of chromosome 8 was, generally, based on isochromosome $8 \mathrm{q}$ formation (J.C. Alers et al., submitted for publication). Deletion of 8p22 sequences was seen by FISH with cosmid DNA probes (Matsuyama et al. 1994a). Likewise, Macoska et al. (1994) showed loss of 8p22 sequences in frozen tissue sections of prostatic tumors by FISH. Further, intratumoral heterogeneity for both ploidy and chromosomal aberrations appeared a prominent feature of prostatic adenocarcinomas (Alers et al. 1995b). Another study by our group described aneuploidy and loss of the $\mathrm{Y}$ chromosome in prostatic intraepithelial neoplastic lesions adjacent to adenocarcinoma (Alers et al. 1995a).

A CGH study by Cher et al. (1994) demonstrated loss of $8 \mathrm{p}$ sequences in a panel of 17 prostatic tumors. Further, $8 \mathrm{p}$ loss and $8 \mathrm{q}$ gain as detected by $\mathrm{CGH}$ correlated with allelic imbalance mapping by a PCR/RFLP study. A subsequent investigation by the same group (Cher et al. 1996) on a panel of regional lymph node and bone metastases showed frequent gain of $8 \mathrm{q}$, as well as loss of $8 \mathrm{p}, 10 \mathrm{q}, 13 \mathrm{q}, 16 \mathrm{q}$, and $17 \mathrm{p}$. Furthermore, a CGH study of 31 primary and 9 recurrent prostatic carcinomas by Visakorpi et al. (1995a) revealed losses of 6q, 8p, 9p, $13 q, 16 q$, and 18q. Allelic loss studies showed a $76 \%$ concordance with $\mathrm{CGH}$ results. Local recurrences that developed during endocrine therapy showed significantly more gains and losses of DNA sequences than primary tumors. Gains of 8q, X, and 7, as well as loss of 8p were particularly involved. Comparable changes were observed by Joos et al. (1995). CGH also revealed that amplification of the chromosome X-linked androgen receptor gene commonly occurs in recurrent tumors during androgen deprivation therapy (Visakorpi et al. 1995b).

\section{Bladder cancer}

Carcinoma in situ or papillomas are presumed to give rise to transitional cell carcinoma (TCC) of the bladder.

4 Fig. 3a-f Interphase ISH of precursor lesions of human epithelial cancers. a-c Barrett's esophagus. a ISH with the chromosome 17-specific centromeric DNA probe to a routinely processed, formalin-fixed, paraffin-embedded section of dysplastic Barrett's esophagus. Most epithelial cell nuclei show two ISH spots; a few aneusomic nuclei can be seen (one is arrowed). b Same area, ISH with a 17 p13 cosmid DNA probe. Most epithelial nuclei display one ISH spot, indicating loss of this chromosomal region. c Same area, p53 immunohistochemistry with monoclonal DO-7 reveals many darkly stained nuclei, indicating overexpression of the p53 protein. These data suggest loss of one p53 gene with mutation of the other. d-f Prostatic intraepithelial neoplasia (PIN). d Hematoxylin-eosin stained section, showing a PIN lesion $(P)$, surrounded by prostatic cancer cells $(T)$. e Detail (left part of the PIN). ISH with the chromosome Y-specific DNA probe, illustrating loss in the luminal cells (arrows), whereas the basal cells have retained this chromosome (arrowheads). f Same area. ISH with the chromosome 1 DNA probe, demonstrating a normal hybridization pattern in the PIN cells. A $40 \times$ objective was used, except for $\mathbf{d}(20 \times)$
ISH of TCC has been reported frequently. A FISH study with repetitive probes on tumor cell suspensions showed monosomy for chromosome 9 as the most frequently occurring abnormality, followed by trisomy for chromosomes 1, 7, and 11 (Hopman et al. 1991). The data suggested that loss of chromosome 9 may be an early event in the development of bladder cancer, while aberrations involving chromosomes 1 and 7 may be important in tumor progression. Waldman et al. (1991) demonstrated in a FISH study on touch preparations of TCCs, monosomy of chromosome 9, as well as overrepresentation of chromosomes 7 and 11. Matsuyama et al. (1994b) performed double-target ISH on 37 cases of bladder cancer. Trisomy 7 , monosomy 9 , and trisomy 10 were detected most frequently. In a study by Poddighe et al. (1992), structural aberrations of chromosome 1 were examined in nuclear suspensions of TCC by FISH with a combination of centromeric (1q12), telomeric (1p36), and library DNA probes. Meloni et al. (1993) demonstrated that FISH analysis on urine and bladder washings is a very useful tool in the diagnosis, early detection, and clinical management of bladder cancer. Sauter et al. (1993) showed heterogeneity in amplification of the erbB-2 oncogene in a small number of cases by dual-labelling FISH with a centromeric probe for chromosome 17 and a cosmid probe for the erbB-2 locus. The suitability of both conventional karyotyping and FISH in the detection of intratumoral heterogeneity in bladder cancers was investigated by Schapers et al. (1993). More recently, Sauter et al. (1994) examined single-cell suspensions from 106 formalin-fixed bladder cancers, as well as touch imprints of 45 fresh bladder tumors, by FISH with probes for the centromeric region of chromosome 17 and a cosmid for the p53 locus on 17p13.1. Double-hybridization experiments showed an increment in the percentage of $17 p$ deletions with advancing tumor stage. Deletion of $17 p$ was also highly correlated with tumor grade and with p53 immunostaining. Similarly, FISH with a p53-specific probe was applied to cell suspensions of a panel of 42 TCCs by Matsuyama et al. (1994c). In 64\% of the specimens, p53 deletion was seen, whereas $38 \%$ showed overexpression at the immunohistochemical level.

A CGH study of 26 mainly high-grade, high-stage TCCs by Kallioniemi et al. (1995) showed losses affecting chromosomes 3p, 8p, 9, 11p, 11q, 17p, and 12q. Gains of DNA sequences were most often found at chromosomal regions distinct from locations of currently known oncogenes. Additionally, a CGH study of 14 lowand high-grade/stage TCCs (Voorter et al. 1995) revealed other regions of amplification. Imbalances involved losses of chromosomes 5, 9, and 11. In half of the cases, loss detected by CGH was also detected by RFLP studies.

\section{Kidney cancer}

Renal cell carcinomas (RCCs) are, in general, adenocarcinomas. FISH has been performed with yeast artificial 
chromosomes to identify the position of translocation breakpoints $(\mathrm{t} 3 ; 6)$ and $\mathrm{t}(3 ; 8)$ in familial $\mathrm{RCC}$ by a number of groups (e.g., Wilke et al. 1994). A FISH study on a small panel of disaggregated archival RCC tissue specimens showed numerical aberrations of chromosomes 1,7 , 17, and Y (Wolman et al. 1993). Abnormal copy numbers of chromosomes 1 and/or 17 in seven out of nine cases had not been identified by previous karyotyping. Beck et al. (1995) performed FISH on single-cell suspensions of 37 RCCs. Numerical aberrations of chromosomes 1 and/or chromosome 7 were present in $18 \mathrm{RCCs}$, and five of these cases showed monosomy for chromosome 1 in more than $50 \%$ of the tumor cells. Section ISH using a large probe set showed that chromosomes 1, 3, 7, and 17 have a higher propensity for aneuploidy than chromosomes 8, 10, 11, 12, and 16 (El-Naggar et al. 1994). Further, these results correlated with DNA flow cytometry.

$\mathrm{CGH}$ in chromophobe RCC, a subtype of RCC, showed specific loss of chromosomes 1, 2, 6, 10, 13, 17, and 21 (Speicher et al. 1994). Moch et al. (1996) found a correlation of genetic changes with clinical outcome. Losses were most prevalent at $3 p, 9 p$, and 13q. Gains were most frequently seen of $5 \mathrm{q}$ and 7 . The same group found a high degree of concordance between $\mathrm{CGH}$ and allelotyping (Presti et al. 1996). Recently, the involvement of 1q gain and $3 p$ loss in metastatic tumor progression was described (Gronwald et al. 1997).

\section{Breast cancer}

Breast cancer comprises ductal and lobular adenocarcinomas, each having a specific precancerous defect, i.e., ductal (DCIS) and lobular carcinoma in situ (LCIS). A considerable number of ISH studies has been published, most often on ductal-type breast carcinoma. Devilee et al. (1988) showed numerical aberrations of chromosome 1 and/or 18 in six out of seven primary breast tumors by performing FISH with centromeric probes. Matsumura et al. (1992) visualized only one copy of a 17p13.1 cosmid DNA probe in nuclei with loss of heterozygosity (LOH) at the $17 \mathrm{p} 13.3$ region, whereas nuclei without $\mathrm{LOH}$ at that locus showed no deletions by FISH. Microdissection followed by FISH was used to identify chromosomal HSRs (Meltzer et al. 1992; Guan et al. 1994). The results indicated amplification of regions $17 \mathrm{q} 12$ (erbB-2 region), 13q21, and 20q12-13.2. Balazs et al. (1995) investigated karyotypic heterogeneity in touch preparations of 23 breast cancers by FISH. Every tumor analyzed showed a heterogenous distribution for at least one chromosome. Micale et al. (1994) revealed gain of chromosome 1 by FISH applied to tissue sections of breast cancers and hyperplastic lesions. Interestingly, aneuploidy for several chromosomes was also seen in the hyperplastic tissue. FISH with a chromosome 17 centromeric probe showed polysomy of chromosome 17 in non-invasive DCIS (Murphy et al. 1995). Further, erbB-2 amplification was seen in both the invasive and non-invasive components within a breast cancer biopsy. Recently, chromosome 1 aneusomy was identified on archival tissue sections of 16 DCISs (Harrison et al. 1995). The authors concluded that chromosome 1 aneusomy precedes invasion and that it is a relatively consistent occurrence in high-grade lesions.

CGH applied to 15 breast cancer cell lines and 33 primary tumors showed increased DNA sequences in twothirds of primary tumors and almost all cell lines (Kallioniemi et al. 1994). Most of these amplified loci were distinct from those of currently known amplified genes in breast cancer, with sequences originating from 17q22-q24 and 20q13 displaying the highest frequency of amplification. Several amplifications, including the ones described above, were observed by Muleris et al. (1994). A study by Ried et al. (1995) showed copy number increases of chromosome $1 \mathrm{q}$ and $8 \mathrm{q}$ sequences. Loss was seen for chromosome $17 \mathrm{p}$ and 22 . Interestingly, Isola et al. (1995) demonstrated that increased copy numbers of chromosomes $8 \mathrm{q}$ and $20 \mathrm{q} 13$ correlated with recurrence rate in node-negative breast cancer and therefore may confer a more aggressive phenotype. Recently, CGH of DCIS revealed gains of 1q, 17q, 19q, and 20q, losses were seen of 13q, 14q, 16q, 17p, and 22q (James et al. 1997). Chromosomal alterations appeared more frequently in higher grades of DCIS.

\section{Ovarian cancer}

Ovarian carcinomas represent a heterogeneous group of tumors, most of them being papillary adenocarcinomas. A recent interphase cytogenetics study by Liehr et al. (1994) revealed specific loss of chromosomes 17 and 20, and gain of chromosomes 1, 7, 8, and 11. Persons et al. (1993) performed FISH with centromeric probes to touch preparations of 25 epithelial ovarian tumors. They showed relative loss of chromosomes 17 and $\mathrm{X}$, as well as a relative gain of chromosomes 12 and 8. Additionally, they showed the HER-2/neu gene to be amplified in 2 of the 25 tumors. Chromosome microdissection followed by FISH was used to identify the chromosomal origin of amplified regions in HSRs of seven ovarian carcinomas (Guan et al. 1995). The results showed that 12 specific chromosome regions are amplified, including 11q, 12q, 16p, 19p, and 19q. These regions may harbor genes important in ovarian cancer tumorigenesis. Recently, gains of chromosomes 6 and 7 were seen in borderline tumors, a presumed precursor condition of ovarian carcinoma (Diebold et al. 1996). CGH of invasive ovarian cancers revealed, most importantly, gain of $3 q$ and $8 \mathrm{q}$ sequences, loss was found most frequently of $16 \mathrm{q}$ and 17 (Iwabuchi et al. 1995). The overall concordance between concurrently performed LOH and reduced copy number by $\mathrm{CGH}$ was $84 \%$.

\section{Discussion and conclusion}

It can be stated that interphase hybridization technology has emerged as an important instrument for the delinea- 
tion of genetic changes in human solid cancers. Results from molecular and karyotyping studies could be confirmed in situ and, in addition, new genetic aberrations are being disclosed. For example, in lung cancer (NSCLC), FISH with region-specific probes showed loss of the p15/p16 region at $9 p$, which is consistent with LOH studies. In head and neck tumors (HNSCC), CGH studies repeatedly identified a new amplified chromosomal region, 3q26-qter. This region has not been described before, and may harbor a new oncogene important in HNSCC development. ISH on colon cancer specimens has confirmed the presence of numerical and structural aberrations frequently encountered in colorectal tumors, such as trisomy 7 and monosomy 18 . It has also added some new numerical aberrations, e.g., gain of chromosome 12. Additionally, $\mathrm{CGH}$ of adenomas revealed gains of chromosome 7 and 20. In prostatic adenocarcinoma, ISH analyses have confirmed chromosomal abnormalities that had been previously detected by karyotyping and LOH studies. However, they appear at much higher frequency than was previously suspected from conventional cytogenetic analysis (e.g., loss of $\mathrm{Y}$ and alterations of chromosome 8). Additionally, ISH analysis rendered possible markers for the biological aggressiveness of prostatic tumors, such as gain of chromosomes 7 and 8. CGH also provided some new regions of interest, most notably the amplification of the $8 \mathrm{q}$ arm. This is, most likely, the result of isochromosome $8 \mathrm{q}$ formation, which is illustrated by a combined ISH/CGH effort in Figs. 1 and 2. In bladder cancer, CGH studies have confirmed some sites of allelic loss, as, for instance, loss of $11 \mathrm{p}$, and have added some interesting new chromosomal regions of amplification. FISH studies of breast cancers with region-specific probes for the $17 \mathrm{p} 13.1$ (p53) region and the $13 \mathrm{q} 14(\mathrm{Rb})$ region were in concordance with LOH studies. FISH was also used to identify the origin of HSRs, a frequently seen abnormality in this type of cancer. One of the amplified oncogenes is the erbB-2 gene on $17 \mathrm{q} 12$. Another, yet unknown, resides in the 20q12-13 region, a site that was revealed by $\mathrm{CGH}$ analysis. The latter technique also distinguished frequent alterations in DCIS, the precursor of invasive ductal carcinoma.

In conclusion, ISH and CGH have established their importance in solid cancer genetics and will continue to gain momentum in this area of research. Microdissection technology (Zhuang et al. 1995) will yield further access to analysis of small tissue areas, which is especially important for CGH studies of precancerous lesions. Furthermore, the increasing and continuing availability of new types of DNA probes, such as phage and bacterial artificial chromosomes (Monaco and Larin 1994), will facilitate the in situ detection of possibly important genetic sites.

Acknowledgements This work was in part supported by the Dutch Cancer Society, grants EUR 92-35, EUR 97-1404, and EUR 97-1478. Dr. C. Rosenberg was supported by the Research School "Molecular Medicine: Pathofysiology of Growth and Differentiation" (OPGD). We further thank Prof. Dr. H.J. Tanke (Department of Cytochemistry and Cytometry, State University Leiden) and Dr. K.K. Krishnadath (Department of Gastroenterology, Erasmus University Rotterdam), for support in these studies.

\section{References}

Alcaraz A, Takahashi S, Brown JA, Herath JF, Bergstrahl EJ, Larson-Keller JJ, Lieber MM, Jenkins RB (1994) Aneuploidy and aneusomy of chromosome 7 detected by fluorescence in situ hybridization are markers of poor prognosis in prostate cancer. Cancer Res 54:3998-4002

Alers JC, Dekken H van (1996) Interphase cytogenetic analysis of solid tumors by non-isotopic DNA in situ hybridization. Prog Histochem Cytochem 31:1-137

Alers JC, Krijtenburg PJ, Vissers KJ, Bosman FT, Kwast ThH van der, Dekken H van (1995a) Interphase cytogenetics of prostatic adenocarcinoma and precursor lesions: analysis of 25 radical prostatectomies and 17 adjacent prostatic intraepithelial neoplasias. Genes Chromosom Cancer 12:241-250

Alers JC, Krijtenburg PJ, Vissers CJ, Bosman FT, Kwast ThH van der, Dekken H van (1995b) Cytogenetic heterogeneity and histologic tumor growth patterns in prostate cancer. Cytometry 21:84-94

Balazs M, Matsumura K, Moore D, Pinkel D, Gray JW, Waldman FM (1995) Karyotypic heterogeneity and its relation to labeling index in interphase breast tumor cells. Cytometry 20:62-73

Bandyk MG, Zhao L, Trocosco P, Pisters LL, Palmer JL, Eschenbach AC van, Chung LWK, Liang JC (1994) Trisomy 7: a potential cytogenetic marker of human prostate cancer progression. Genes Chromosom Cancer 9:19-27

Baretton GB, Valina C, Vogt T, Schneiderbanger K, Diebold J, Löhrs U (1994) Interphase cytogenetic analysis of prostatic carcinomas by use of nonisotopic in situ hybridization. Cancer Res 54:4474-4480

Beck JLM, Hopman AHN, Feitz WFJ, Schalken J, Schaafsma HE, Kaa CA van de, Ramaekers FCS, Hanselaar AGJM, Wilde PCM de (1995) Numerical aberrations of chromosomes 1 and 7 in renal cell carcinomas as detected by interphase cytogenetics. J Pathol 176:123-135

Bishop JM (1991) Molecular themes in oncogenesis. Cell 64:235-248

Bockmuhl U, Schwendel A, Dietel M, Petersen I (1996) Distinct patterns of chromosomal alterations in high- and low-grade head and neck squamous cell carcinomas. Cancer Res 56:5325-5329

Boveri T (1914) Zur frage der entstehung maligner tumoren. Fisher, Jena

Brown JA, Alcaraz A, Takahashi S, Persons DL, Lieber MM, Jenkins RB (1994) Chromosomal aneusomies detected by fluorescent in situ hybridization analysis in clinically localized prostate carcinoma. J Urol 152:1157-1162

Brzoska PM, Levin NA, Fu KK, Kaplan MJ, Singer MI, Gray JW, Christman MF (1995) Frequent novel DNA copy number increase in squamous cell head and neck tumors. Cancer Res 55:3055-3059

Cajulis RS, Frias-Hidvegi D (1993) Detection of numerical chromosomal abnormalities in malignant cells in fine needle aspirates by fluorescence in situ hybridization of interphase cell nuclei with chromosome-specific probes. Acta Cytol 37:391-396

Chen TR, Nierman WC (1994) Chromosome painting and quantitative karyotyping of colon adenocarcinoma cell lines, DLD-1 and HCT-15. Anticancer Res 14:109-112

Cher ML, MacGrogan D, Bookstein R, Brown JA, Jenkins RB, Jensen RH (1994) Comparative genomic hybridization, allelic imbalance, and fluorescence in situ hybridization on chromosome 8 in prostate cancer. Genes Chromosom Cancer $11: 153-162$

Cher ML, Bova GS, Moore DH, Small EJ, Carroll PR, Pin SS, Epstein JI, Isaacs WB, Jensen RH (1996) Genetic alterations in 
untreated metastases and androgen-independent prostate cancer detected by comparative genomic hybridization and allelotyping. Cancer Res 56:3091-3102

Dekken H van, Alers J (1993) Loss of chromosome Y in prostatic cancer cells, but not in stromal tissue. Cancer Genet Cytogenet 66:131-132

Dekken H van, Pizzolo JG, Kelsen DP, Melamed MR (1990a) Targeted cytogenetic analysis of gastric tumors by in situ hybridization with a set of chromosome-specific DNA probes. Cancer 66:491-497

Dekken H van, Pizzolo JG, Reuter VE, Melamed MR (1990b) Cytogenetic analysis of human solid tumors by in situ hybridization with a set of 12 chromosome-specific DNA probes. Cytogenet Cell Genet 54:103-107

Devilee P, Thierry RF, Kievits T, Kolluri R, Hopman AHN, Willard HF, Pearson PL, Cornelisse CJ (1988) Detection of chromosome aneuploidy in interphase nuclei from human primary breast tumors using chromosome-specific repetitive DNA probes. Cancer Res 48:5825-5830

Diebold J, Deisenhofer I, Baretton GB, Blasenbreu S, Suchy B, Schneiderbanger K, Meier W, Haas CJ, Löhrs U (1996) Interphase cytogenetic analysis of serous ovarian tumors of low malignant potential: comparison with serous cystadenomas and invasive serous carcinomas. Lab Invest 75:473-485

Dietzsch E, Lukeis RE, Vrazas V, Hasthorps S, Garson OM (1994) Characterization of homogeneously staining regions in a small cell lung cancer cell line, using in situ hybridization with a mycn probe. Genes Chromosom Cancer 10:213-216

El-Naggar AK, Dekken H van, Ensign LG, Pathak S (1994) Interphase cytogenetics in paraffin-embedded sections from renal cortical neoplasms. Correlation with cytogenetic and flow cytometric DNA ploidy analyses. Cancer Genet Cytogenet 73:134-141

Gronwald J, Storkel S, Holtgreve-Grez H, Hadaczek P, Brinkschmidt C, Jauch A, Lubinski J, Cremer T (1997) Comparison of DNA gains and losses in primary renal clear cell carcinomas and metastatic sites: importance of $1 \mathrm{q}$ and $3 \mathrm{p}$ copy number changes in metastatic events. Cancer Res 57:481-487

Guan X-Y, Meltzer PS, Dalton WS, Trent JM (1994) Identification of cryptic sites of DNA sequence amplification in human breast cancer by chromosome microdissection. Nat Genet $8: 155-161$

Guan X-Y, Cargile CB, Anzick SL, Thompson FH, Meltzer PS, Bittner ML, Taetle R, McGill JR, Trent JM (1995) Chromosome microdissection identifies cryptic sites of DNA sequence amplification in human ovarian carcinoma. Cancer Res 55:3380-3385

Harrison M, Magee HM, O'Loughlin J, Gorey TF, Dervan PA (1995) Chromosome 1 aneusomy, identified by interphase cytogenetics, in mammographically detected ductal carcinoma in situ of the breast. J Pathol 175:303-309

Heim S, Mitelman F (1987) Cancer cytogenetics. Liss, New York

Henke R-P, Kruger E, Ayhan N, Hubner D, Hammerer P (1994) Frequency and distribution of numerical chromosomal aberrations in prostatic cancer. Hum Pathol 25:476-484

Herbergs J, Bruine AP de, Marx PTJ, Vallinga MIJ, Stockbrugger RW, Ramaekers FCS, Arends JW, Hopman AHN (1994) Chromosome aberrations in adenomas of the colon, proof of trisomy 7 in tumor cells by combined interphase cytogenetics and immunohistochemistry. Int J Cancer 57:781-785

Hopman AHN, Moesker O, Smeets AW, Pauwels RP, Vooijs GP, Ramaekers FC (1991) Numerical chromosome 1, 7, 9, and 11 aberrations in bladder cancer detected by in situ hybridization. Cancer Res 51:644-651

Hunter S, Gramlich T, Abbott K, Varma V (1993) Y chromosome loss in esophageal carcinoma: an in situ hybridization study. Genes Chromosom Cancer 8:172-177

Isola FJ, Fallioniemi O-P, Chu LW, Fuqua SAW, Hilsenbeck SG, Osborne CK, Waldman FM (1995) Genetic aberrations detected by comparative genomic hybridization predict outcome in node-negative breast cancer. Am J Pathol 147:905-911

Iwabuchi H, Sakamoto M, Sakunaga H, Ma Y-Y, Carcangiu ML, Pinkel D, Yang-Feng TL, Gray JW (1995) Genetic analysis of benign, low grade, and high-grade ovarian tumors. Cancer Res 55:6172-6180

James LA, Mitchell ELD, Menasce L, Varley JM (1997) Comparative genomic hybridization of ductal carcinoma in situ of the breast: identification of regions of DNA amplification and deletion in common with invasive breast carcinoma. Oncogene 14:1059-1065

Jones E, Zhu XL, Rohr LR, Stephenson RA, Brothman AR (1994) Aneusomy of chromosomes 7 and 17 detected by FISH in prostate cancer and the effects of selection in vitro. Genes Chromosom Cancer 11:163-170

Joos S, Bergerheim US, Pan Y, Matsuyama H, Bentz M, Manoir S du, Lichter P (1995) Mapping of chromosomal gains and losses in prostate cancer by comparative genomic hybridization. Genes Chromosom Cancer 14:267-276

Kallioniemi A, Kallioniemi O-P, Piper J, Tanner M, Stokke T, Chen L, Smith HS, Pinkel D, Gray JW, Waldman FM (1994) Detection and mapping of amplified DNA sequences in breast cancer by comparative genomic hybridization. Proc Natl Acad Sci USA 91:2156-2160

Kallioniemi A, Kallioniemi O-P, Citro G, Sauter G, DeVries S, Kerschmann R, Caroll P, Waldman F (1995) Identification of gains and losses of DNA sequences in primary bladder cancer by comparative genomic hybridization. Genes Chromosom Cancer 12:213-219

Kim SY, Lee JS, Ro JY, Gay ML, Hong WK, Hittelman WN (1993) Interphase cytogenetics in paraffin sections of lung tumors by non-isotopic in situ hybridization. Am J Pathol 142:307-317

Knudson AG (1971) Mutation and cancer: statistical study of retinoblastoma. Proc Natl Acad Sci USA 68:820-823

Krishnadath KK, Tilanus HW, Alers JC, Mulder AH, Dekken H van (1994) Detection of genetic changes in Barrett's adenocarcinoma and Barrett's esophagus by DNA in situ hybridization and immunohistochemistry. Cytometry 15:176-184

Krishnadath KK, Tilanus HW, Blankenstein M van, Hop WCJ, Teijgeman R, Mulder AH, Bosman FT, Dekken H van (1995) Accumulation of genetic abnormalities during neoplastic progression in Barrett's esophagus. Cancer Res 55:1971-1976

Lese CM, Rossie KM, Appel BN, Reddy JK, Johmso JT, Myers EN, Gollin SM (1995) Visualization of INT2 and HST1 amplification in oral squamous cell carcinomas. Genes Chromosom Cancer 12:288-295

Levin NA, Brzoska P, Gupta N, Minna JD, Gray JW, Christman MF (1994) Identification of frequent novel genetic alterations in small cell lung carcinoma. Cancer Res 54:5086-5091

Levin NA, Brzoska PM, Warnock ML, Gray JW, Christman MF (1995) Identification of novel regions of altered DNA copy number in small cell lung tumors. Genes Chromosom Cancer 13:175-185

Liehr T, Stubinger A, Thoma K, Tulusan HA, Gebhart E (1994) Comparative interphase cytogenetics using FISH on human ovarian carcinomas. Anticancer Res 14:183-188

Macoska JA, Trybus TM, Sakr WA, Wolf MC, Benson PD, Powell I-J, Pontes JE (1994) Fluorescence in situ hybridization analysis of $8 \mathrm{p}$ allelic loss and chromosome 8 instability in human prostate cancer. Cancer Res 54:3824-3830

Matsumura K, Kallioniemi A, Kallioniemi O, Chen L, Smith HS, Pinkel D, Gray J, Waldman FM (1992) Deletion of chromosome $17 \mathrm{p}$ loci in breast cancer cells detected by fluorescence in situ hybridization. Cancer Res 52:3474-3477

Matsuyama H, Pan Y, Skoog L, Tribukait B, Naito K, Ekman P, Lichter P, Bergerheim US (1994a) Deletion mapping of chromosome $8 \mathrm{p}$ in prostate cancer by fluorescence in situ hybridization. Oncogene 9:3071-3076

Matsuyama H, Bergerheim US, Nilsson I, Pan Y, Skoog L, Tribukait B, Ekman P (1994b) Nonrandom numerical aberrations of chromosomes 7, 9, and 10 in DNA-diploid bladder cancer. Cancer Genet Cytogenet 77:118-124

Matsuyama H, Pan Y, Mahdy EA, Malmstrom PU, Hedrum A, Uhlen M, Busch C, Hirano T, Auer G, Tribukait B, Naito K, Lichter P, Ekman P, Bergerheim USR (1994c) P53 deletion as a genetic marker in urothelial tumor by fluorescence in situ hybridization. Cancer Res 54:6057-6060 
Meloni AM, Peier AM, Haddad FS, Powell IJ, Block AW, Huben RP, Todd I, Potter W, Sandberg AA (1993) A new approach in the diagnosis and follow-up of bladder cancer. FISH analysis of urine, bladder washings, and tumors. Cancer Genet Cytogenet 71:105-118

Meltzer PS, Guan X-Y, Trent JM (1992) Rapid generation of region specific probes by chromosome microdissection and their application. Nat Genet 1:24-28

Micale MA, Visscher DW, Gulino SE, Wolman SR (1994) Chromosomal aneuploidy in proliferative breast disease. Hum $\mathrm{Pa}$ thol 25:29-35

Mitelman F (1994) Catalog of chromosome aberrations in cancer, 5 th edn. Wiley-Liss, New York

Moch H, Presti JC, Sauter G, Buchholz N, Jordan P, Mihatsch MJ, Waldman FM (1996) Genetic aberrations detected by comparative genomic hybridization are associated with clinical outcome in renal cell carcinoma. Cancer Res 56:27-30

Monaco AP, Larin Z (1994) YACs, BACs, PACs and MACs: artificia chromosomes as research tools. Trends Biotechnol 12:280-286

Muleris M, Almeida A; Gerbault-Seureau M, Malfoy B, Dutrillaux B (1994) Detection of DNA amplification in 17 primary breast carcinomas with homogeneously staining regions by a modified genomic hybridization technique. Genes Chromosom Cancer 10:160-170

Murphy DS, McHardy P, Coutts J, Mallon EA, George WD, Kaye SB, Brown R, Keith WN (1995) Interphase cytogenetic analysis of erbB2 and topoll $\alpha$ co-amplification in invasive breast cancer and polysomy of chromosome 17 in ductal carcinoma in situ. Int J Cancer 64:18-26

Nowell PC (1976) The clonal evolution of tumor cell populations. Acquired genetic lability permits stepwise selection of variant sublines and underlies tumor progression. Science 194:23-28

Nowell PC, Hungerfold DA (1960) Chromosome studies on normal and leukaemic human leukocytes. J Natl Cancer Inst 25:85-88

Persons DL, Hartmann LC, Herath JF, Borell TJ, Cliby WA, Keeney GL, Jenkins RB (1993) Interphase molecular cytogenetic analysis of epithelial ovarian carcinomas. Am J Pathol 142:733-741

Petersen I, Langreck H, Wolf G, Schwendel A, Psille R, Vogt P, Reichel MB, Ried T, Dietel M (1997) Small cell lung cancer is characterized by a high incidence of deletions on chromosomes 3q, 4q, 5q, 10q, 13q and 17p. Br J Cancer 75:79-86

Poddighe PJ, Ramaekers FC, Smeets AW, Vooijs GP, Hopman AH (1992) Structural chromosome 1 aberrations in transitional cel carcinoma of the bladder: interphase cytogenetics combining a centromeric, telomeric, and library DNA probe. Cancer Res 52:4929-4934

Presti JC, Moch H, Reuter VE, Cordon-Cardo C, Waldman FM (1996) Renal cell carcinoma genetic analysis by comparative genomic hybridization and restriction fragment length polymorphism analysis. J Urol 156:281-285

Ried T, Petersen I, Holtgreve-Grez H, Speicher MR, Schrock E, Manoir S du, Cremer T (1994) Mapping of multiple DNA gains and losses in primary small cell lung carcinomas by comparative genomic hybridization. Cancer Res 54:1801-1806

Ried T, Just KE, Holtgreve-Grez H, Manoir S du, Speicher MR, Schröck E, Latham C, Blegen H, Zetterberg A, Cremer T, Auer G (1995) Comparative genomic hybridization of formalinfixed, paraffin embedded breast tumors reveals different patterns of chromosomal gains and losses in fibroadenomas and diploid and aneuploid carcinomas. Cancer Res 55:5415-5423

Ried T, Knutzen R, Steinbeck R, Blegen H, Schrok E, Heselmeyer K, Manoir S du, Auer G (1996) Comparative genomic hybridization reveals a specific pattern of chromosomal gains and losses during the genesis of colorectal tumors. Genes Chromosom Cancer 15:234-245

Rosai M (1996) Ackerman's surgical pathology, 8th edn. Mosby, St. Louis

Sandberg AA (1990) The chromosomes in human cancer and leukemia, 2nd end. Elsevier Science Publishing, New York

Sasaki K, Sato T, Kurose A, Uesugi N, Ikeda E (1995) Monosomy of chromosome 18 detected by fluorescence in situ hybridization in colorectal tumors. Cancer 76:1132-1138
Sauter G, Moch H, Moore D, Carroll P, Kerschmann R, Chew K, Mihatsch M, Gudat F, Waldman F (1993) Heterogeneity of erbB-2 gene amplification in bladder cancer. Cancer Res 53:2199-2203

Sauter G, Deng G, Moch H, Kerschmann R, Matsumura K, Devries S, George T, Fuentes J, Carroll P, Mihatsch M, Waldman F (1994) Physical deletion of the p53 gene in bladder cancer: detection by fluorescence in situ hybridization. Am J Pathol 144:756-766

Schapers R, Smeets W, Hopman A, Pauwels R, Geraedts J, Ramaekers F (1993) Heterogeneity in bladder cancer as detected by conventional chromosome analysis and interphase cytogenetics. Cancer Genet Cytogenet 70:56-61

Schlegel J, Stumm G, Scherthan H, Bocker T, Zirngibl H, Rüschoff J, Hofstädter F (1995) Comparative genomic in situ hybridization of colon carcinomas with replication error. Cancer Res 55:6002-6005

Speicher MR, Schoell B, Manoir S du, Schrock E, Ried T, Cremer T, Storkel S, Kovacs A, Kovacs G (1994) Specific loss of chromosomes $1,2,6,10,13,17$, and 21 in chromophobe renal cell carcinomas revealed by comparative genomic hybridization. Am J Pathol 145:356-364

Speicher MR, Howe C, Crotty P, Manoir S du, Costa J, Ward DC (1995) Comparative genomic hybridization detects novel deletions and amplifications in head and neck squamous cell carcinomas. Cancer Res 55:1010-1013

Steiner MG, Harlow SP, Colombo E, Bauer KD (1993) Chromosomes 8,12 , and 17 copy number in Astler-Coller stage $\mathrm{C}$ colon cancer in relation to proliferative activity and DNA ploidy. Cancer Res 53:681-686

Takahashi S, Qian J, Brown JA, Alcaraz A, Bostwick DG, Lieber MM, Jenkins RB (1994) Potential markers of prostate cancer aggressiveness detected by fluorescence in situ hybrdization in needle biopsies. Cancer Res 54:3574-3579

Tsuji T, Mimura Y, Maeda K, Ida M, Sasaki K, Shinozaki F (1994) Numerical abberations of chromosome 17 detected by FISH with DNA-specific probes in oral tumors. Anticancer Res 14:1689-1693

Visakorpi T, Hyytinen E, Kallioniemi A, Isola J, Kallioniemi O-P (1994) Sensitive detection of chromosome copy number aberations in prostate cancer by fluorescence in situ hybridization. Am J Pathol 145:624-630

Visakorpi T, Kallioniemi A, Syvänen A-C, Hyytinen ER, Karhu R, Tammela T, Isola JJ, Kallioniemi O-P (1995a) Genetic changes in primary and recurrent prostate cancer by comparative genomic hybridization. Cancer Res 55:342-347

Visakorpi T, Hyytinen E, Koivisto P, Tanner M, Keinanen R, Palmberg C, Palotie A, Tammela T, Isola J, Kallioniemi O-P (1995b) In vivo amplification of the androgen receptor gene and progression of human prostate cancer. Nat Genet 9:401-406

Vogelstein B, Fearon ER, Hamilton SR, Kern SE, Preisinger AC, Leppert M, Nakamura Y, White R, Smits AM, Bos JL (1988) Genetic alterations during colorectal tumor development. N Engl J Med 319:525-532

Voorter C, Joos S, Bringuier PP, Vallinga M, Poddighe P, Schalken J, Manoir S du, Ramaekers F, Lichter P, Hopman A (1995) Detection of chromosomal imbalances in tansitional cell carcinoma of the bladder by comparative genomic hybridization. Am J Pathol 146:1341-1354

Voravud N, Shin DM, Ro JY, Lee JS, Hong WK, Hittelman WN (1993) Increased polysomies of chromosomes 7 and 17 during head and neck multistage tumorigenesis. Cancer Res 53:2874-2883

Waldman FM, Carroll PR, Kerschmann R, Cohen MB, Field FG, Mayall BH (1991) Centromeric copy number of chromosome 7 is strongly correlated with tumor grade and labeling index in human bladder cancer. Cancer Res 51:3807-3813

Wilke CM, Guo SW, Hall BK, Boldog F, Gemmill RM, Chandrasekharappa SC, Barcroft CL, Drabkin HA, Glover TW (1994) Multicolor FISH mapping of YAC clones in 3p14 and identification of a YAC spanning both FRA3B and the $\mathrm{t}(3: 8)$ associated with hereditary renal cell carcinoma. Geneomics 22:319-326 
Wolman SR, Waldman FM, Falazs M (1993) Complementarity of interphase and metaphase chromosome analysis in human tumors. Genes Chromosom Cancer 6:17-23

Worsham MJ, Wolman SR, Carey TE, Zarbo RJ, Benninger MS, Dyke DL van (1995) Common clonal origin of synchronous primary head and neck squamous cell carcinoma. Hum Pathol 26:251-261

Xiao S, Li D, Corson JM, Vijg J, Fletcher JA (1995) Codeletion of p15 and p16 genes in primary non-small cell lung carcinoma. Cancer Res 55:2968-2971
Zhuang Z, Bertheau P, Emmert-Buck MR, Liotta LA, Gnarra J, Linehan WM, Lubensky IA (1995) A microdissection technique for archival DNA analysis of specific cell populations in lesions $<1 \mathrm{~mm}$ in size. Am J Pathol 146:620-625

Zitzelsberger H, Szucs S, Weier HU, Lehmann L, Braselmann H, Enders S, Schilling A, Breul J, Höfler H, Bauchinger M (1994) Numerical abnormalities of chromosome 7 in human prostate cancer detected by fluorescence in situ hybridization (FISH) on paraffin-embedded tissue sections with centromerespecific DNA probes. J Pathol 172:325-335 